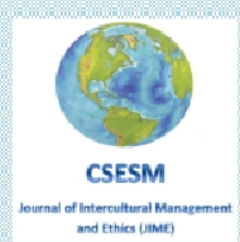

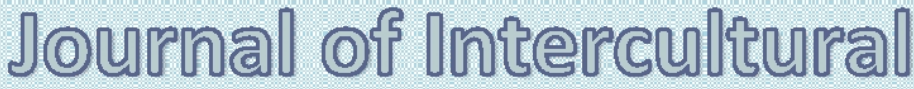

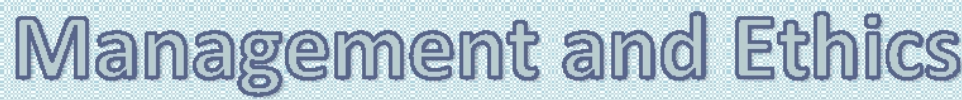

\author{
I0ME
}

ISSN 2601 - 5749, ISSN-L 2601 - 5749

Center for Socio-Economic Studies and Multiculturalism

lasi, Romania

WWW csesmioirg 


\section{TABLE OF CONTENT}

Editorial

Iulian Warter

Where Did Culture Come From? Evolutionary Foundations of Cultural Diversity

Paulo Finuras

Crash: Boeing and the Power of Culture

Thomas D. Zweifel, Vip Vyas

Political Culture, Social Polarization and Electoral Behavior. The Last Decade in Romanian

Political System

Silviu-Petru Grecu

The Principles of Transparency and Judging Others Favorably: The Talmudic View

Hershey H. Friedman, Robert B. Fireworker

Some Issues Regarding the Ethics of the Management at Romanian State-Owned

Companies .55

Baluta Aurelian Virgil, Rada Alexandru Cristian

How Does Logistics Command of the Military Navy Support Local Development and

Cultural Integration?

Rosa Caiazza

Illusion and Disillusion. Case Studies about the Constitution of a New Political Party in

Romania

Alexandru Muraru

How Could We Overcome the Feeling Of Insecurity? Explorations in the Spectrum of Polyscopic Consciousness

Anton Carpinschi

The Employees' Perceptions, Practices and Experiences Regarding the Strategic Process

Carried Out In the Public Hospitals

Ana Niculita 


\title{
THE EMPLOYEES' PERCEPTIONS, PRACTICES AND EXPERIENCES REGARDING THE STRATEGIC PROCESS CARRIED OUT IN THE PUBLIC HOSPITALS
}

\author{
Ana Niculita \\ Academy of Economic Studies of Moldova, Republic of Moldova \\ E-mail: aniculita82@gmail.com
}

\begin{abstract}
The conduct of the institutional strategic process is the responsibility of institutional management. However, the involvement of employees in this process is considered to be very important to increase the level of motivation and commitment to the institutional vision, mission, values, the achievement of strategic objectives and planned changes. It also reduces the resistance of employees to these changes.

The purpose of the study is to assess employees' perceptions, practices and experiences of the strategic process carried out in public hospital institutions. In the study participated employees of public hospitals with higher medical education, but also with higher education of other specialties (accountants, economists, lawyers, procurement specialists, etc.), who also have an important role in the strategic process, for the realization of its provisions in accordance with their positions of the organization. For this purpose, a survey was developed in the interest of the study, containing 39 questions, structured in six chapters. The information presented in the study is structured into five fields: employee involvement in the institutional strategic process; institutional vision, mission and values; involvement in objectives setting; strategy implementation; strategy monitoring.
\end{abstract}

Keywords: strategic process, strategy, public hospitals.

\section{Introduction}

Involvement of employees in the institutional strategic process. The institutional strategic process involves an organizational change, which, to be successful, must be agreed by the employees concerned. The involvement of the institution's employees in the development of the strategy and its implementation means involving them in the process of change and development of the organization. The process of change is easier when the members of the organization are encouraged and motivated to understand the strengths and weaknesses of the organization, the direction of development, when they are involved in the planning and decision-making process. Otherwise, resistance to change occurs and group cohesion is damaged, which negatively influences the willingness to engage in strategic processes (Burduș \& Popa, 2014; Bryson, 2002; Băcanu, 2014). Also, in the scientific literature (Burduș \& Popa, 2014; Bryson, 2002; Hrebiniak, 2009; Brătianu, 2000) there are various recommendations regarding the communication of institutional strategy. The employees of the institution should be aware of its provisions and be directly involved in its development and implementation.

Institutional vision, mission, and values. The process of establishing the strategy begins with determining the vision of the institution, which represents an ideal state projected into the future and which shapes the possible and desirable development of the organization. The vision must generate an attitude of confidence in the future and in the possibilities of the organization to develop in the sense of transposing it into action, stimulating the effective and creative participation of the whole team. A good vision is shared and accepted by all 
members of the organization and gives them the opportunity to build the motivation to implement it (Radu, 2007).

The mission of an organization is the general expression of its reason for existing and creating value for society. In other words, it clarifies the purpose of an organization or the reasons why it should do what it does. The formalization of the mission is done through a formal statement, called a mission statement. It gives meaning to individuals and groups within the organization to work together for the common good (Burduș \& Popa, 2014; Bryson, 2002).

The correct formulation of the mission, the involvement of employees in its formulation, and its appropriate publicity contribute to strengthening the internal environment of the organization by fortifying the organizational climate, establishing a unique way of allocating resources, identifying the direction of development of the institution by each employee, and distributing the organization's results to strategic units, departments and even positions (Radu, 2007).

An organization cannot exist without a solid system of values, without them being internalized and shared by the people who make it up. To understand the values promoted, commitment is needed from both management and employees. Organizational values are a factor of uniqueness and personality: they define the organization's processes, decisions and actions (Kinicki \& Williams, 2017).

Involvement in setting objectives. It is known from the scientific literature (Hrebiniak, 2009; Radu, 2007) that involving employees at the stage of setting objectives and actions to be taken, considerably increases the level of responsibility and commitment of personnel towards them.

Strategy implementation. The process of strategy implementation is a participatory one, which has several features (Burduş \& Popa, 2014): (1) focus on the strategic directions of the organization, which will lead to changes in the process structure and personnel structure of the organization; (2) consideration of the plan of actions to achieve the strategy as a unified and integrated process; (3) individuals and collectives within the organization will be directed to use competencies to improve coordination at all hierarchical levels and to make the process of achieving strategic goals more efficient.

Monitoring the strategy. Monitoring is the ongoing process of data collection and analysis through which the progress of the strategy is regularly measured against set objectives and expected results. It tracks compliance with the implementation schedule, identifies causes of non-compliance and takes the necessary steps to improve operational performance. Monitoring is usually the responsibility of those involved in the strategy implementation process (IDIS Viitorul, 2014). For this reason, hospital employees also play an important role in this process.

\section{Materials and methods}

The hypothesis of the study is that the institutional strategic process is a formal one and often the employees of the hospitals are not involved in this process, because they do not know or do not understand this process.

The purpose of the study is to assess employees' perceptions, practices and experiences of the strategic process carried out in public hospitals. This will allow to understand the level of the employees' involvement in the development and implementation of the institutional strategies. This is the first study in this field in the Republic of Moldova.

In order to achieve the proposed objective, a descriptive, cross-sectional, quantitative study was conducted by interviewing employees of public hospital institutions. The perceptions, practices and experiences of personnel in the institutional strategic process were assessed. 
The Survey for the Analysis of Management Strategies within the Medical Institutions, administered to employees of public hospitals, is a questionnaire developed for the purpose of the study, containing 39 questions. The questions are closed-ended, the respondent has the option to select the option he/she thinks appropriate, but there is also the option, for most of the questions, to give another answer than the one proposed or to clarify the selected answer option. The questions were structured in 6 chapters: General characteristics of the health care institution and employees; Setting the overall strategy; Formulating the strategy; Communicating the strategy; Implementing the strategy; Monitoring, reviewing and evaluating the strategy.

Inclusion criteria for completing the Survey for the Analysis of Management Strategies within the Medical Institutions were: to be employed in a public hospital institution; verbal agreement to participate in the study; higher education; questionnaire to be confidential and anonymous. Criteria for exclusion from the study were: lack of agreement to participate, medical personnel with secondary education.

The sample of employees in public hospitals was calculated based on the total number of doctors working in hospital institutions: 3515 doctors in 2017 (Agenția Națională pentru Sănătate Publică, 2018).

The following calculation formula was applied to ensure a representative sample:

$$
\mathrm{n}=\frac{\mathrm{N} \times \mathrm{t}^{2} \times \mathrm{P} \times \mathrm{q}}{\mathrm{N} \times \Delta^{2}+\mathrm{t}^{2} \times \mathrm{P} \times \mathrm{q}},
$$

where,

$\mathrm{n}$ - sample volume

$\mathrm{N}$ - value of the studied phenomenon

$\mathrm{t}-$ probability factor $=1,96(95 \%)$

$\mathrm{P}$ - probability of occurrence of the phenomenon

$\mathrm{q}-$ counter probability, $\mathrm{q}=1-\mathrm{P}$

$\Delta$ - permissible limit error $=0,05(5 \%)$

Thus, applying the calculation formula, we obtained $n=346$, to which we added a $10 \%$ rate of non-medical personnel: $\mathrm{n}^{1}=346+10 \%$ (non-medical personnel) $=381$. We also added the $10 \%$ non-response rate and obtained: $n^{2}=381+10 \%$ (non-response) $=419$.

The surveys for the analysis of management strategies in medical institutions were collected in public hospitals operating on the territory of the Republic of Moldova from March to June 2019.

Methods of analysis of the results: IBM SPSS Statistics 23, MS Excel.

\section{Results}

In the study participated 422 respondents from 16 public hospital institutions of different levels: 3 institutions of republican level, 3 institutions of municipal level, 9 institutions of district level and 1 departmental hospital. Thus, almost half of the respondents (49.1\%) are employees of district hospitals, every fourth respondent $(25.1 \%)$ works in a tertiary/ republican level hospital institution, $20.6 \%$ are employees of municipal hospitals and $5.2 \%$ of the respondents work in a departmental institution.

The medical employees with higher education, who at the time of the survey held a managerial position or not, were included in the study. Six out of ten respondents are employees with executive positions: $53.4 \%$ - doctors and $9.5 \%$ employees with higher education in other specialties (accountants, economists, lawyers, procurement specialists, etc.), who also have an important role in the strategic process, to achieve its provisions in accordance with the functions of the organization. Four out of ten respondents are employees with managerial position of different hierarchical level: $29.5 \%$ are heads of wards and 
services, $2.6 \%$ are heads of clinics/departments, reporting to other subdivisions, $3.8 \%$ deputy directors and $1.2 \%$ - hospital directors.

The majority of respondents $(87.6 \%)$ have medical education; however each tenth $(9.7 \%)$ also has studies in other related fields, such as economics, law, public health management, etc. At the same time, $12.4 \%$ have other than medical studies, most of which are also in economics and law.

The research reveals that almost half of the employees of public hospitals (47\%) do not have training / studies in the field of management. Most of those who have training / studies in the field of management are those who have short-term continuing education courses (1-2 weeks) - 30.4\%, each tenth respondent (10.4\%) states that participated in longterm continuing education courses (3-4 weeks). Only $12.3 \%$ of respondents say they have a bachelor's degree $(4.2 \%)$ or a master's degree $(8.1 \%)$ in management.

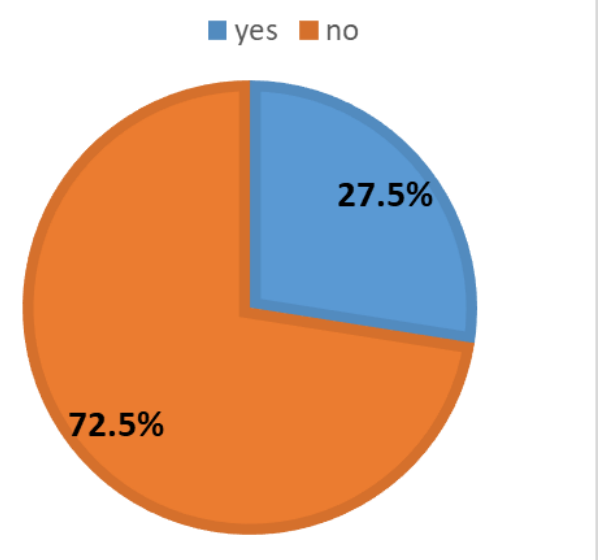

Figure 1. Participation in training in the field of strategic management / strategic planning / elaboration and implementation of strategies

Only about a quarter $(27.5 \%)$ of the respondents stated that they participated in training in the field of strategic management / strategic planning / development and implementation of strategies (Fig. 1).

Employees' involvement in the strategic institutional process. Research shows that most employees of public hospitals $(66.2 \%)$ perceive strategy as a real tool / plan that can be implemented. However, 1/3 of employees do not support this view: $13.8 \%$ said that strategy is a formal tool, which is developed for hierarchically superior and control bodies, and $19.8 \%$ did not know how to respond (Fig. 2). The analysis by categories of personnel reveals that the share of operational personnel who did not know how to determine the strategy is 3 times higher than that of managerial personnel.

Employees' perception from public hospitals is that in $72.3 \%$ of cases the strategic development directions of the institution correspond in full $(61.5 \%)$ or partially $(10.8 \%)$ with the provisions of state policy documents in the field of health (Fig. 3). At the same time, one out of four respondents did not know how to answer this question. 


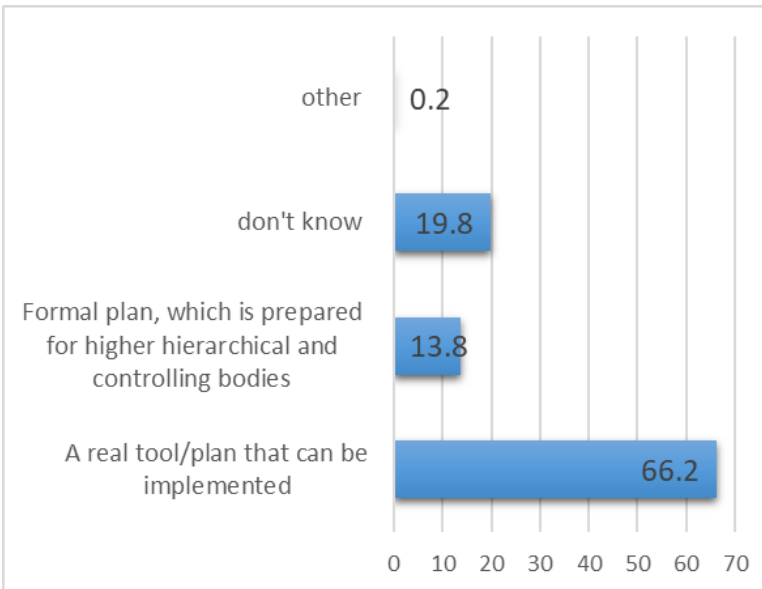

Figure 2. Perception of the institution's strategy, $\%$

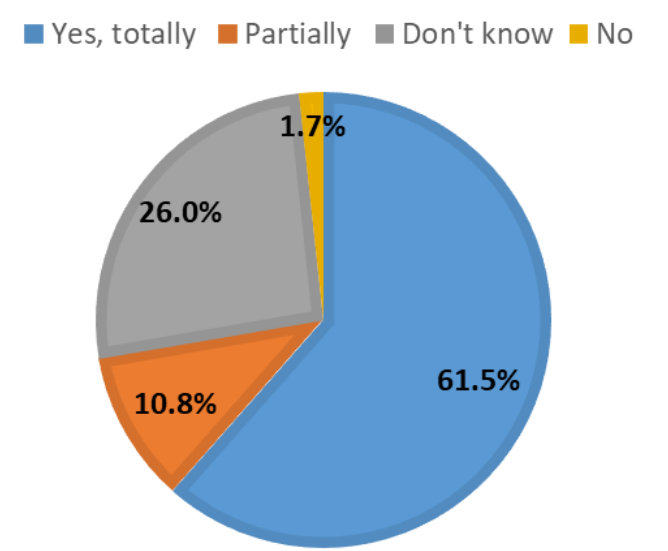

Figure 3. Correspondence of the strategic development directions of the institution with the provisions of the state policy documents in the field of health

At the stage of establishing the general strategy, more than half of the respondents employed by the hospital institutions $(54.5 \%)$ state that they are involved (each time or depending on their area of responsibility / competence) in the decision-making process that related to the long-term development of the institution, $17.6 \%$ - sometimes or rarely, and $28 \%$ - never. The long-term decision-making process is directly related to the planning and allocation of resources. In this context, two control questions were asked, with the aim of confirming or refuting the results obtained above. At the stage of formulating the strategy, the respondents were asked if they are involved in planning the resources for the implementation of the provisions of the strategy. Thus, 51.3\% answered in the affirmative (yes, every time or yes, depending on their area of responsibility / competence), $15.5 \%$ answered that they are involved sometimes or rarely, and a third $(33.3 \%)$ - never. At the strategy implementation stage, respondents had to determine whether they were involved in making decisions regarding the allocation of resources for the implementation of the strategy. Less than half (48.6\%) confirmed that they are involved every time or in their area of responsibility/ competence, $15.4 \%$ are involved sometimes or rarely and $35.9 \%$ - never get involved.

Vision, mission and institutional values. Being asked if they agree with the vision of the institution in which they operate, $3 / 4(74.8 \%)$ of the employees of the public hospitals answered affirmatively, $22.1 \%$ of the respondents do not know if the institution has a vision and $2.9 \%$ do not agree with the approved vision. The analysis of this component by personnel categories reveals that the share of operational personnel who do not know if there is a vision at the institutional level is $12.6 \%$ higher than that of personnel holding a managerial position.

According to the results of the study, four out of ten employees $(38.4 \%)$ of public hospitals state that they participated in the elaboration of the mission of their institution, the share of managerial and operational personnel being approximately equal in this respect $(19.3 \%$ and $19.1 \%)$. The share of respondents who did not participate in the elaboration of the mission is $61.6 \%$. Out of these, the share of those who did not participate and do not know whether the institution has a mission is twice as high as they know that the institution has a mission, but they, for some reason, did not participate in its elaboration.

The analysis of the level of involvement in the elaboration of the institutional values reveals the fact that the studied sample can be divided in three equal parts. The proportion of respondents who participated in the determination of values $(35.1 \%)$ is approximately equal to that of respondents who know that the institution has a set of values but did not participate in their elaboration $(33.7 \%)$ and only slightly higher than that of the respondents who stated 
that they did not participate in the elaboration of the set of values and do not know if they exist in the institution $(31.2 \%)$.

Being asked to name three institutional values, we found that $76.1 \%$ of public hospital employees could not name any value of the institution in which they operate and only in one institution, $91 \%$ of employees were able to name 3 values each.

Among the values named by the respondents were: professionalism, quality of services/medical act, fairness, patient satisfaction, team spirit, flexibility, dedication, performance, responsibility, etc. At the same time, in this compartment, a series of activities were indicated, which represent non-values: micro invasive surgery, endovascular surgery, correct financial reporting, medical transport, computerization of the institution, etc.

Being asked about the way to make known the mission, vision, values and general objectives of the institution, the personnel of public hospital institutions identified the meetings chaired by the director of the institution (62.9\%) as the most important way of communication. Every third respondent mentioned the institution's website $(33.3 \%)$ as a tool used in communicating the components of the strategy. Bilateral meetings with managers to communicate this topic were attended by $1 / 4$ respondents $(26.4 \%)$, and $15.2 \%$ - received it as information on the employment order. At the same time, $15.4 \%$ of employees mentioned that they did not need to be notified because they participated in their development and know them, and $12.1 \%$ acknowledged that the components of the strategy were not made known to them or don't know them. Other ways of communication with a lower share (total $16.2 \%$ ), mentioned by respondents were: e-mail, brochures, laminated cards, posters, newsletters, etc. (fig. 4)

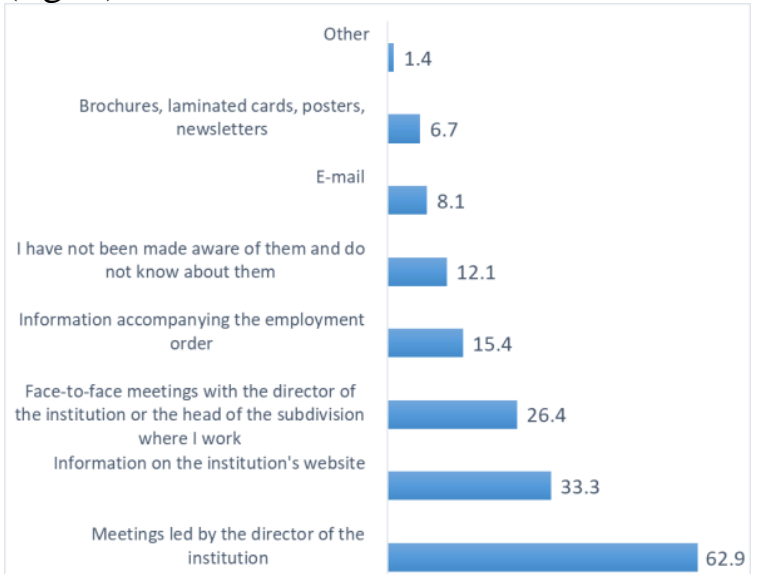

Figure 4. The way to make known the mission, vision, values, and general objectives of the institution, $\%$

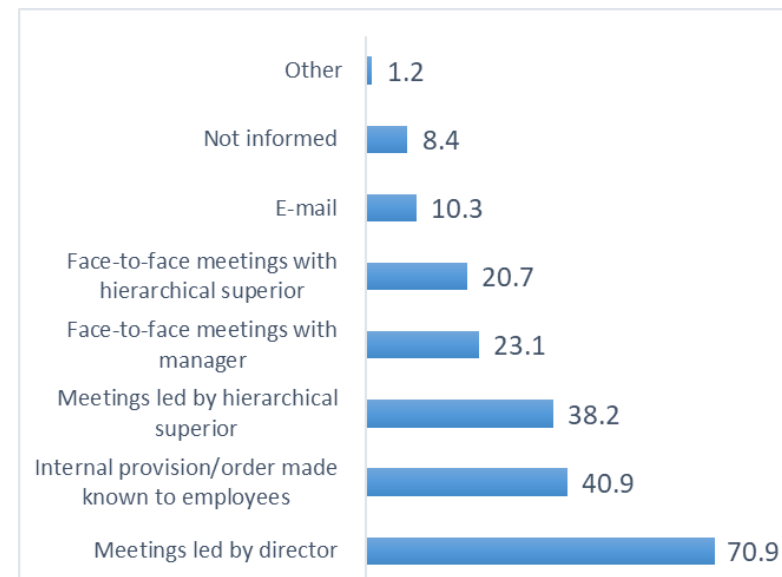

Figure 5. The way to inform employees what to do to implement the strategy, \%

Involvement in setting objectives. The employees of public hospitals, being asked if they participated in the elaboration of strategic objectives, only $24.9 \%$ answered affirmatively, which means that only 1 out of 4 employees actively participate in this process, the share of managerial personnel in this respect being higher than of the operational one with 7 percentage points. Also, four out of ten respondents $(42.9 \%)$ state that the strategic objectives have been developed by senior managers and they have already received them approved to implement them, and every third employee (32.2\%) does not participated in this process and does not even know them.

The analysis by categories of personnel reveals that the share of operational personnel who received strategic objectives from senior managers to implement them is twice as high as that of managerial personnel (28.2\% versus $14.6 \%)$, and the share the operational personnel who did not participate in the elaboration of the strategic objectives and do not know them is three times higher than that of the managers $(24.8 \%$ versus $7.5 \%)$. 
The stage of harmonizing the objectives of the subdivisions with the strategic objectives of the hospital institution is also perceived differently by the employees. $63.3 \%$ of hospital personnel state that the objectives of the subdivisions are developed in accordance with the strategic objectives. At the same time, $13.1 \%$ show that the subdivisions or some subdivisions do not have their own objectives, and 1/4 $(23.5 \%)$ of the respondents state that they do not know if there are objectives for each subdivision, the share of operational personnel in this regard being $15.4 \%$ higher than the managerial personnel.

The main modalities selected by the respondents were the meetings: those led by the director $(70.9 \%)$ and those led by the hierarchical superior $(38.2 \%)$, but also the internal dispositions / orders brought to the notice of the employees (40.9\%). Bilateral meetings with the manager of the institution and those with the hierarchical superior are much less often used in communication with employees: $23.1 \%$ and $20.7 \%$, respectively, and the use of email for this purpose is very low (10.3\% ). In addition, $8.4 \%$ of employees state that they were not informed about what they have to do to implement the strategy (fig. 5)

The implementation of the strategy begins with determining the role and responsibilities of the parties involved. Following the study, we determined that the role and responsibilities of public hospital employees in the process of achieving strategic objectives are perceived as clear by four out of ten respondents (40.3\%). The others state that they are more involved in daily activities and less in achieving strategic objectives (39.3\%) or it is not their responsibility to achieve strategic objectives and their role is different. Therefore, more than half of the respondents do not notice the connection between the strategic objectives and the operational activities whose purpose is to achieve these objectives.

The process of integrating the objectives of the subdivisions into the institutional strategy is considered difficult by the majority of public hospital employees $(60.2 \%)$ and not at all difficult by only $3.8 \%$ of respondents. The fact that the strategy facilitates the formulation and achievement of the objectives of the subdivision is aware of three out of ten respondents $(30.7 \%)$, and $5.3 \%$ state that the subdivision in which it operates does not have its own objectives (Fig. 6).

The co-working with other subdivisions within the institution to implement strategic objectives is also qualified by hospital personnel, in most cases, as difficult (41.1\%) or satisfactory (27.8\%). The share of respondents who consider the co-working with other subdivisions as good or very good is $31 \%$ (fig. 7 )

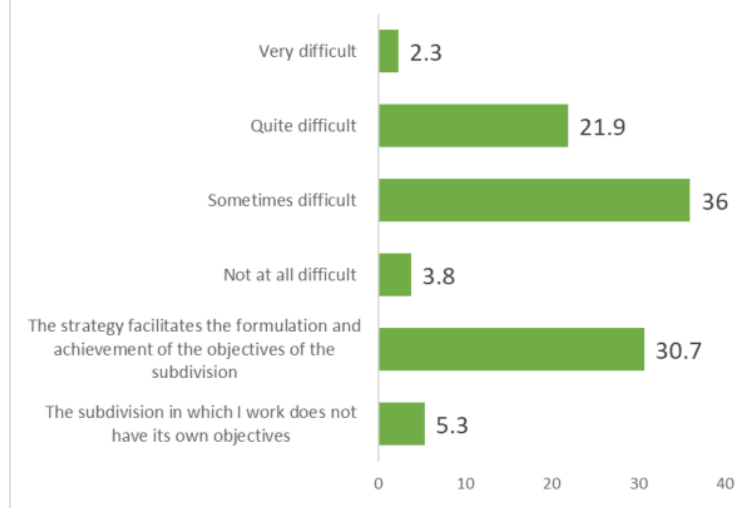

Figure 6. Process of integrating the objectives of the subdivisions into the institutional strategy, $\%$

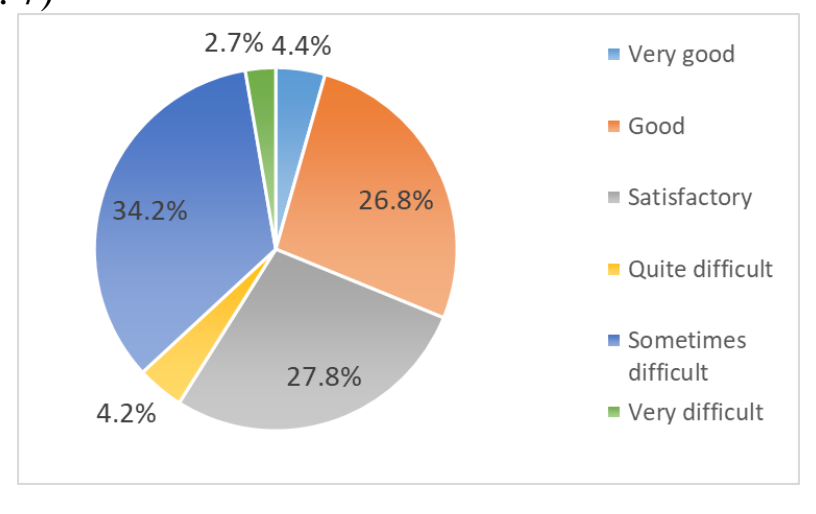

Figure 7. Collaboration with other subdivisions within the institution for the implementation of strategic objectives

Implementing the strategy. Three out of ten respondents $(29.5 \%)$ state that they participated in the elaboration of the action plan of the institutional strategy. The analysis by categories of personnel shows that the share of managerial personnel, in this sense, is higher 
than that of operational personnel by 7.2 percentage points. $43.1 \%$ employees of public hospitals state that they did not participate in the development of the action plan, but have already received it approved to implement it. Out of these, the share of operational personnel $(28.2 \%)$ who are involved only in the implementation of the action plan is twice as high as that of managerial personnel (14.9\%). Also, $1 / 4$ of the respondents $(23.8 \%)$ state that they did not participate in the process of developing the plan and do not know what its provisions are, and the share of operational personnel in this regard is 3.5 times higher than of the managerial one. At the same time, 3.7\% state that there is no strategy action plan in the institution.

The perception of the majority of public hospitals employees (64.4\%) regarding the allocation of resources for the implementation of the strategy is that there are not enough resources. Some of the respondents $(53.8 \%)$ state that, even if resources are not enough, they still identify ways to optimize their use, and another part $(10.6 \%)$ believe that resources are not enough, but there are no possibilities for increasing them. The share of personnel who believe that resources are sufficient is about five times lower (13\%). In this context, $3.1 \%$ of respondents believe that resources are sufficient, but they are used inefficiently, and the share of respondents who do not know about the allocation of resources for the implementation of the strategy is $22.6 \%$ (Fig. 8).

The employees of hospital institutions were offered a list of actions to attract financial resources for achieving strategic objectives. $1 / 3$ of the respondents $(34.5 \%)$ stated that in this sense all the mentioned ways are welcome, and every third employee selected the option of attracting external resources as the best way. The options for coordinating activities with other subdivisions to make more efficient use of resources and redirect existing resources according to current strategic priorities have accumulated a percentage of $7.8 \%$ and $6.1 \%$, respectively, which indicates that separately these methods are used quite rarely. A weight of $7.3 \%$ accumulated the mixing of two of the options listed above, and $15.2 \%$ hesitated to expose themselves to this topic (fig. 9).

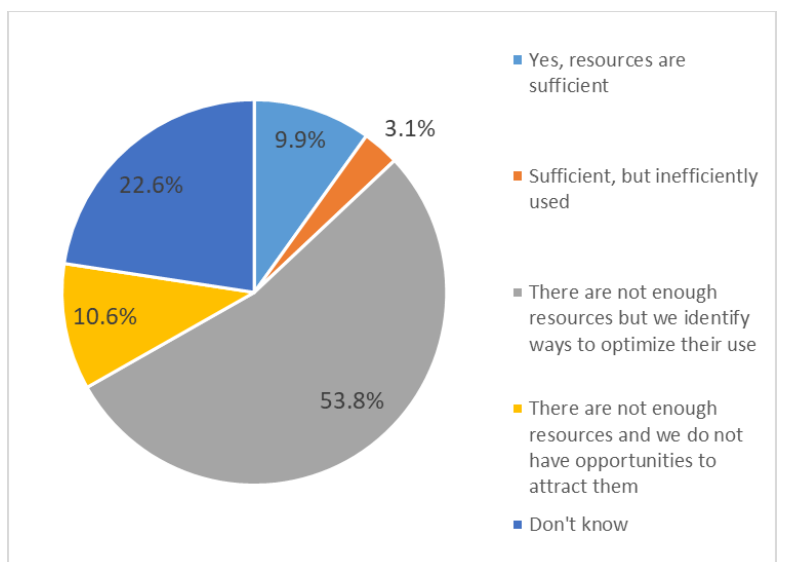

Figure 8. Allocation of resources for the implementation of the strategy

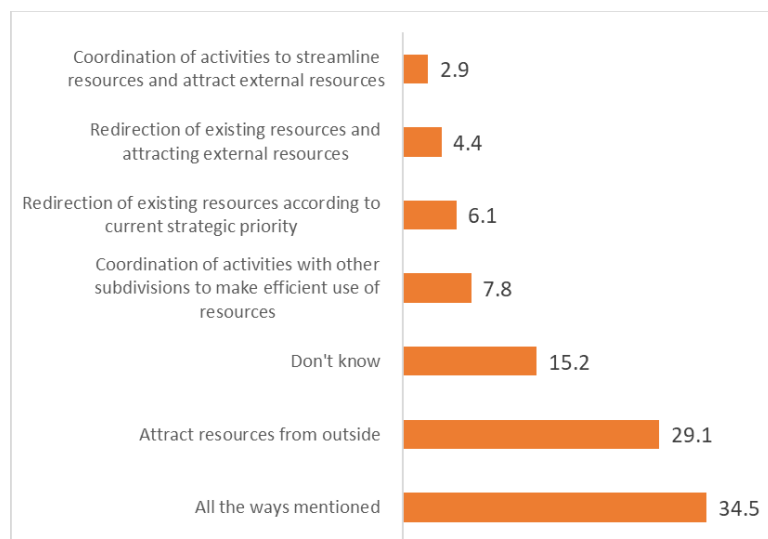

Figure 9. Additional actions to attract financial resources for achieving strategic objectives, $\%$

Despite the above mentioned during the analysis, more than half of hospital employees $(57.8 \%)$ believe that the results of the implementation of the strategy are clear and concrete. $12.7 \%$ were skeptical about the results: they are vague and unrealistic $(6.0 \%)$ or do not believe in achieving certain results $(6.7 \%)$. Only $5.2 \%$ said that no expected results have been defined as a result of implementing the strategy, and 1/4 of respondents said they did not know whether results had been defined. The analysis by personnel category reveals that the proportion of operational personnel stating that they do not know whether results have been defined is 5 times higher than that of managerial personnel. 
Strategy monitoring. According to the results of the study, more than half of the respondents employees of public hospitals (54.7\%) state that they are involved in the process of monitoring the strategy: $7.3 \%$ - each time and $47.4 \%$ - if it belongs to their field responsibility or competence. $14.2 \%$ state that they are involved in this process sometimes or rarely, and every third respondent $(31.1 \%)$ - never.

The tools most often used in monitoring the strategy at institutional level are the presentation of information at the request of senior managers (40.7\%) and the systematic presentation of reports (40.7\%). Also, $37.3 \%$ of hospital personnel state they participate in monitoring sessions. At the same time, 1/4 of employees do not participate in this process and do not know the tools used to monitor the strategy.

As a result of the research conducted, we found that every third respondent $(29.4 \%)$ considered that the strategy should be reviewed annually and around $1 / 3$ considered that the strategy should be reviewed: monthly $(12.7 \%)$, quarterly $(14,2 \%)$ or half-yearly $(5.6 \%)$. The share of those who believe that the strategy should never be revised is very low at $0.8 \%$, and $3.3 \%$ believe that it should be done when necessary. The share of respondents who do not know and are not involved in the strategy review process is relatively high, at $34 \%$. These data show that public hospital employees do not understand their essence, importance, and role in reviewing the institutional strategy.

\section{Discussions}

In order to ensure the effective involvement of the employees of the public hospitals in the institutional strategic process, they need to have knowledge in the field of management and/or strategic management. The results of the study show that approximately half of the employees of public hospitals (with or without managerial position) do not have training / studies in management field and only about a quarter participated in training in the field of strategic management / strategic planning / development and implementation of strategies.

Among the people who stated that they do not have training in this field are also people who hold managerial positions of different hierarchical level. In particular, a difference for those who do not have training in strategic management, compared to those who do, can be seen in lower-level managers. And if in the republican level institutions, the heads of departments / services are placed hierarchically on the fourth or fifth level after the director, deputy director, head of clinic, head of department, head of department, head of service, then in district hospitals they are usually two or three levels above, which indicates their important role in the strategic process.

The activity of public medical institutions is regulated from a technical and administrative point of view, and decisions on development directions, financing priorities and investments are coordinated with hierarchically superior authorities in the field of health, public finance, taxation, etc. It is important for employees of public institutions to know that the strategic development directions of the institution correspond to the provisions of the state policy documents in the field of health. Most of them consider that the strategic development directions of the institution correspond in full or partially with the provisions of state policy documents in the field of health.

About half of the employees are involved in the decision-making process related to the long-term development of the institution, less than half are involved in decisions-making on the allocation of resources for the implementation of strategic provisions, and three out of ten - in developing the action plan of the strategy. The analysis of these results reveals that there is a tendency to decrease the share of respondents involved in making strategic decisions (each time or depending on its field of responsibility / competence) and to increase the share of those who are never involved in such activities. 
The study shows that one out of five respondents do not know if the institution has a vision, more than half did not participate in the elaboration of the mission, and 2/3 of them did not participate in the elaboration of the values. Low involvement in the determination of these components is demonstrated by the inability of most employees to name three institutional values at a time. This can negatively affect employees' motivation to work together and to achieve institutional performance. Also, the fact that $1 / 3$ of the employees see the web page as a tool used in communicating the components of the strategy, demonstrates their non-involvement in the strategy development process. The website is usually used for external communication, and for communication with employees, managers should use other tools.

Only one out of four employees participated in setting the strategic objectives, and most respondents consider the process of integrating the objectives of the subdivisions into the institutional strategy difficult. Most respondents perceive that they are more involved in daily activities and less in achieving strategic objectives or it is not their responsibility to achieve strategic objectives and their role is different. This demonstrates that employees see the strategic process as something separate from the institutional activity. The analysis of the ways of communicating what the employees have to do to carry out the strategy reveals a system of top-down communication, mainly bureaucratic.

Four out of ten employees of public hospitals state that they did not participate in the development of the action plan, but have already received it approved to implement it, which reveals the low involvement of respondents in the decision-making process. Also, most of the respondents consider that there are not enough resources for implementation of the strategies.

Half of the respondents state that they are involved in the strategy monitoring process and consider the most commonly used monitoring tools: presenting information at the request of senior managers, presenting reports, participating in monitoring meetings.

\section{Conclusions}

1. The low knowledge in the field of strategic management/ strategic planning is an impediment to the involvement of the employees of the public hospitals in the institutional strategic process.

2. The results of the study show that setting the vision, mission and institutional values is often a formal activity, which the employees are not always involved in, and the communication system at the institutional level is top-down, a bureaucratic one.

3. The study emphasizes that the employees of the public hospitals do not notice the connection between the accomplishment of the operational activities that have as finality the achievement of the strategic objectives and of the strategy, in general.

4. The obtained results determine the need to strengthen the capacity of employees in field of strategic management/ strategic planning. Also, the institutional strategic process has to be approached as a participatory process, in which the employees of public institutions are involved, along with the top-level managers, in order to ensure the achievement of the institutional performance.

\section{References}

Burduș, E., \& Popa, I. (2014). Metodologii manageriale. București: Pro Universitaria.

Bryson, J.M. (2002). Planificarea strategică pentru organizații publice și nonprofit. Ghid pentru consolidarea și susținerea realizărilor organizaționale. Chișinău: ARC.

Băcanu, B. (2014). Anti-Strategic Management: teorie și studii de caz. Iași: Polirom.

Hrebiniak, L.G. (2009). Strategia în afaceri. Implementarea și executarea eficientă. București: ALL.

Brătianu, C. (2000). Management strategic. Bucureşti: Ceres. 
Radu P. (2007). Management strategic. Iași: Sedcom Libris.

Kinicki, A., \& Williams, B. K. (2017). Management. O introducere practică. București: Educational Centre.

IDIS Viitorul (2014). Ghid practic de elaborare a strategiilor raionale de dezvoltare socioeconomică. Chișinău. http://www.viitorul.org/files/library/4517306_md_857110_md_ghid.pdf

Agenția Națională pentru Sănătate Publică (2018). Anuarul statistic al sistemului de sănătate din Moldova pentru anul 2017. Indicii de activitate ai IMSP. https://cloud.mail.ru/public/3MzJ/5eQEQUcxD/3.\%20RAPOARTE\%20DE\%20ACTI VITATE\%20A\%20INSTITUTIILOR\%20MEDICO-

SANITARE/Sanatatea\%20publica\%20in\%20Moldova\%202017/03.\%20Indicii\%20de $\% 20$ activitate $\% 20 \mathrm{a} \% 20 \mathrm{IMSP}$.pdf 